\title{
Ras GTPase-Activating Protein 1
}

National Cancer Institute

\section{Source}

National Cancer Institute. Ras GT Pase-Activating Protein 1. NCI Thesaurus. Code C91777.

Ras GT Pase-activating protein 1 (1047 aa, $\sim 116 \mathrm{kDa}$ ) is encoded by the human RASA1 gene. This protein is involved in the regulation of Ras family GT Pases. 